\title{
First Report of Alternaria zinniae causing Blight in Zinnia sp. from Kashmir, India
}

\author{
K.A. Bhat*, N.A. Bhat, F.A. Bhat, T.A. Wani and H.S. Viswanath \\ Division of plant Protection, Faculty of Agriculture Wadura, Sher-i-Kashmir University of \\ Agricultural Sciences and Technology of Kashmir, India \\ *Corresponding author
}

\section{A B S T R A C T}

Keywords

Alternaria zinniae, Zinniae, Kashmir, Foliar blight.

Article Info

Accepted:

29 June 2017

Available Online:

10 July 2017
Zinniae is an important flower specie cultivated in India as well as in Kashmir valley. An unusual disease outbreak was observed in the nursery beds of Zinniae elegans. During ascertaining the cause of the disease a new pathogen Alternaria zinniae not previously reported from this region was found infecting the plants causing moderate to heavy blight. During the study Alternaria zinniae infecting Zinniae sp. was reported first time in the valley of Kashmir.

\section{Introduction}

Zinniae is an old garden favorite with many cultivars. It is a bushy, leafy annual. In Kashmir valley Zinniae is commonly grown flower specie grown both for commercial as well as aesthetic purpose. In Kashmir valley Zinniae was previously reported to be effected mostly by Cercospora zinniae, which was considered the only major fungal disease and constraint for profitable cultivation of this flower plant.

In the present report one more fungal pathogen is being reported to cause moderate to heavy leaf blight in nursery plantation of Zinniae sp. Nursery laid down in faculty campus of Faculty of Agriculture Wadura was seen effected by blight symptoms which were unusual and not seen before in this region
(Figure 1). Upon microscopic observation spores of Alternaria sp. were found associated with the blight infection. The causal pathogen was isolated and kochs postulates were followed to ascertain pathogenicity of the cause of this disease.

\section{Microscopic examination}

The microscopic examination of the diseased tissue reveled association of a particular Alternaria $S p$. with the disease.

The Alternaria spores were with a very long beak characteristic of Alternaria zinniae (Pape, 1942). 


\section{Isolation and purification of causal fungi}

The leaf tissues partly infected were brought to laboratory surface sterilized followed with serial washings with sterile water, blotting dry with sterile blotting paper towels and were inoculated on PDA Plates (Johnston and Booth, 1983; Waller et al., 1998). The fungal colony obtained was purified with both hyphal tip method (Pathak, 1972) and single spore technique (Johnston and Booth, 1983). The purified culture obtained, produced similar spores which were associated with the diseased tissue.

\section{Pathogenicity test}

The isolated pure culture which had produced abundant spores was used to conduct this test. The spores were washed from the Petri dish with the help of sterilized distilled water. A spore load of $10^{5} / \mathrm{ml}$ was used to inoculate Zinniae plants with the help of miny sprayer.

Figure-1: Foliar blight out break in Zinnia nursery

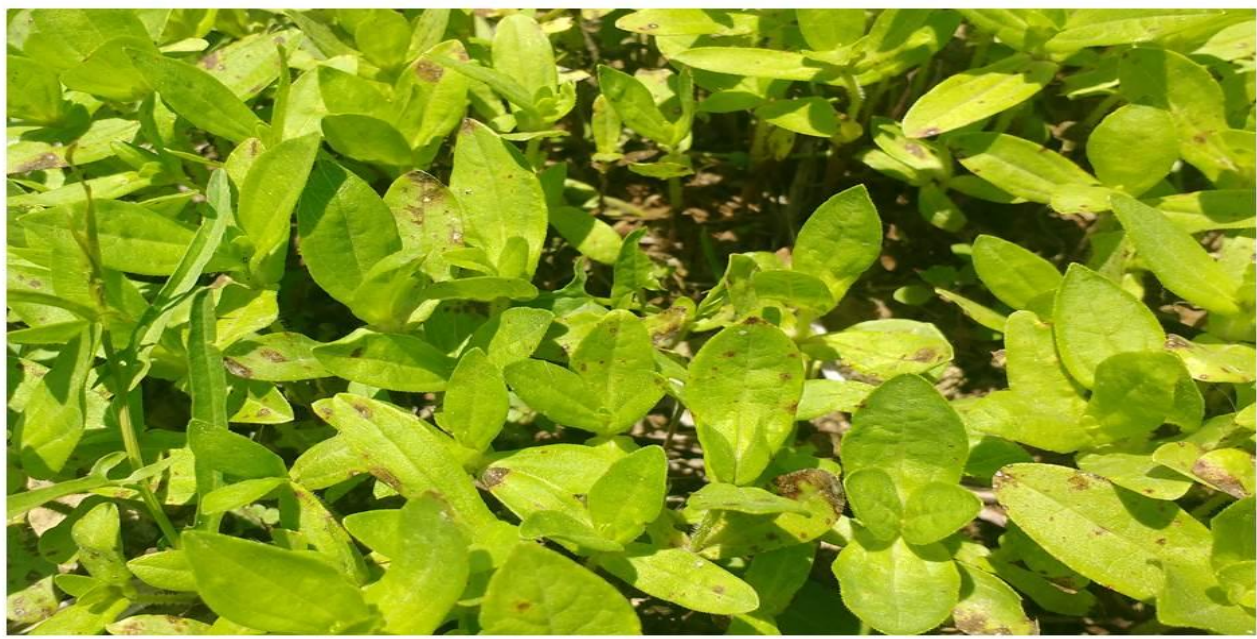

Figure-2: Pathogenicity test on Host (Zinnia elegans)

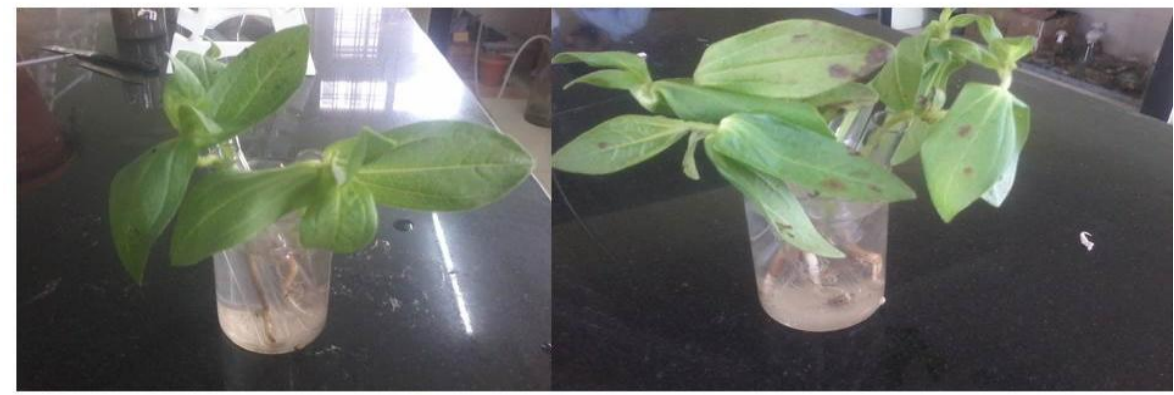

At the time of inoculation

96 hours after inoculation of pathogen 
Figure-3: Micrograph of conedia of Causal pathogen
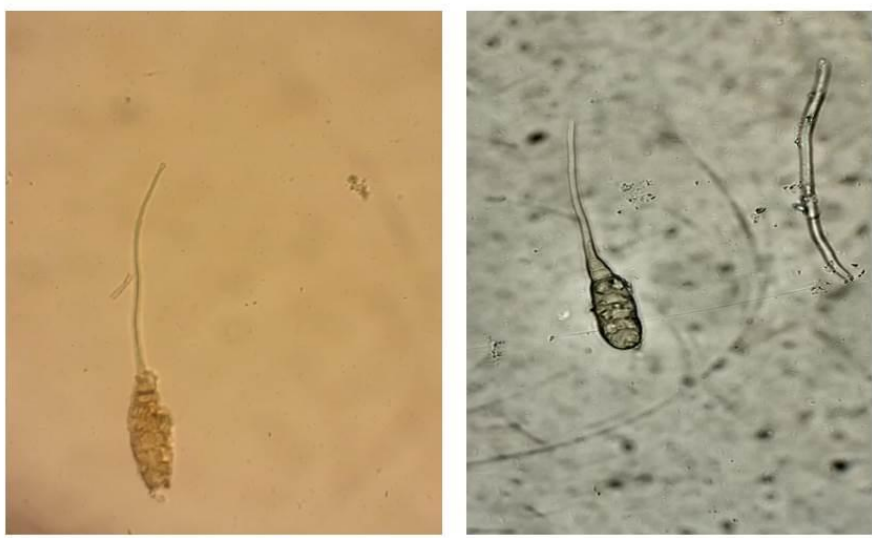

Cor

Figure-4: Alternaria Zinniae in culture on Potato Dextrose Agar(PDA)

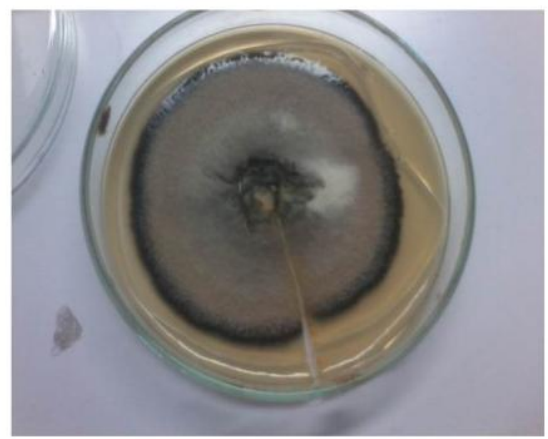

The inoculated plants were kept in humidity chamber and observed daily. The symptoms started to develop after 48 hours of inoculation and after 96 hours typical blight symptoms were quite clear (Figure 2).

These infected produced similar Alternaria spores with typical very long beak. Upon reisolation of the fungal from these artificially inoculated plants similar fungal colony were obtained proving all the necessary conditions of Koch's postulates.

\section{Characters of causal pathogen}

Upon identification of the fungal pathogen all the characteristics especially that of the spore (100-200 $\mu$ x 13-23 $\mu$ ) having exceptionally very long beak $(54-95 \mu)$ not normally seen in other species of Alternaria is suggestive to the pathogen Alternaria zinniae (Figures 3 and 4). The spores are darker with 6-10 transverse septa and also rarely with longitudinal septa. The cultures are initially grayish black turning darker with time with dark blackish borders (Figure-4). The identification was carried out using standard literature (Pape, 1942; Annonymous, 2017).

Alternaria zinniae was first described in 1942. The first publication on the disease in the United States appears in 1943 (Diamock et al., 1943), besides Zinniae, A. zinniae has been found to infect other hosts such as Sunflower, tomato, lettuce, tobacco and China aster (Wehlburj, 1969).

Although Zinniae is grown in Kashmir valley 
from a very long time but only few pathogens were reported associated with this plant. To our knowledge Alternaria zinniae causing Alternaria leaf blight of Zinniae is not previously reported from Valley of Kashmir and present study reporting the presence of this pathogen from this region is the first one from Kashmir valley. Besides we were unable to trace presence of this causal pathogen infecting Zinniae Sp. in Fungi of India and in Indian Type Culture Collection as per their Catalogue of Fungal and Bacterial Collection (1936-2016).

\section{References}

Annonymous. 2017. Alternaria Zinniae. Mycobank No.284043.

Dimock, A.W. and Osborn, J.H. 1943. An Alternaria disease of zinniae.
Phytopathol., 33: 372-381.

Pape, H. 1942. Die Alternaria-Krankheit der Zinniae und ihre Bekämpfung. Angewandte Botanik., 24: 61-79.

Johnston, A., and Booth, C. 1983. Plant Pathologists Pocket Book. Commonwealth Mycological Institute, Kew, Surrey, England, P.439.

Pathak, V.N. 1972. Essentials of Plant Pathology, Prakesh Publishers, Jaipur, India, p. 448.

Waller, J.M., Ritchie, B.J., and Holderness, M. 1998. Plant Clinic Handbook, CAB International New York, NY.

Wehlburj, C. 1969. Two Leaf Spot Diseases of Zinniae, Florida Department of Agriculture, October 1969 Division of Plant Industry. Plant Pathol. Circular, No 86.

\section{How to cite this article:}

Bhat, K.A., N.A. Bhat, F.A. Bhat, T.A. Wani and Viswanath, H.S. 2017. First Report of Alternaria zinniae causing Blight in Zinnia Sp. from Kashmir, India. Int.J.Curr.Microbiol.App.Sci. 6(7): 3964-3967. doi: https://doi.org/10.20546/ijcmas.2017.607.409 